Sulaev I.Kh. Gela Guniava. Gela Guniava. The Muslim Community of the Caucasus in the Georgian Archival Docu-ments. Years 1800-1917: a Collection of Documents. - The City of Qom (Republic of Iran). - 2013. 600 pp. // Islamovedenie. 2017. V. 8. № 2. P. 106-118

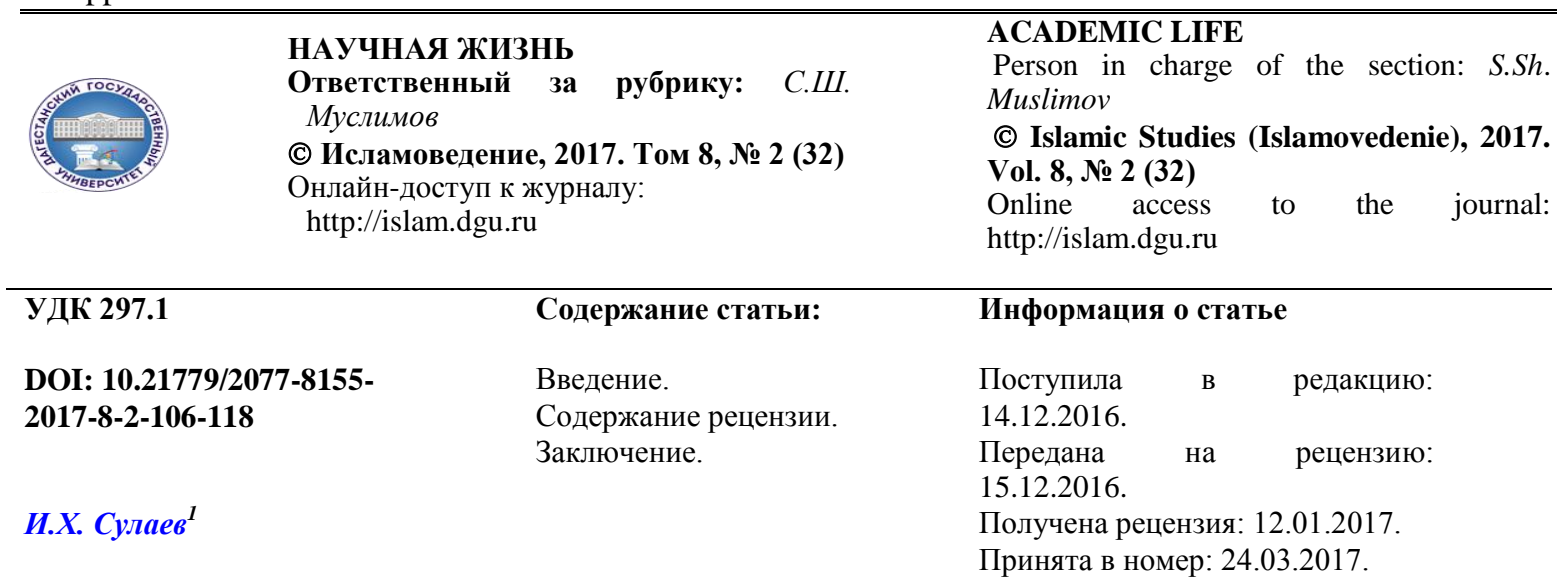

Гела Гуниава. Исламская община Кавказа по документам грузинских архивов. 1800-1917 гг.: сборник документов. - г. Кум (Республика Иран). - 2013. - 600 с.

Дагестанский государственный университет; sigab.ru@yandex.ru

Сборник документов Гела Гуниава «Исламская община Кавказа по документам грузинских архивов. 1800-1917 гг.» включает десятки документов, отражающих деятельность исламских институтов в Закавказье и взаимоотношения царской колониальной администрации с «официальным» духовенством. Сборник представляет большой научный интерес для исламоведов, религиоведов, историков, политологов и других исследователей, а также для широкого круга читателей.

Ключевые слова: закавказские духовные правления шиитского и суннитского учений, наместник Кавказа, ислам, мечети.

UDC 297.1

DOI: 10.21779/20778155-2017-8-2-106-118

I.Kh. Sulaev ${ }^{2}$
The content of the article

Introduction.

The content of the review.

Conclusion.

\section{Information about the article}

Received: 14.12.2016.

Submitted for review: 15.12.2016.

Review received: 12.01.2017.

Accepted for publication: 24.03.2017.

\title{
Gela Guniava. The Muslim Community of the Caucasus in the Georgian Archival Documents. Years 1800-1917: a Collection of Documents. - The City of Qom (Republic of Iran). - 2013. - $600 \mathrm{pp}$.
}

\section{Dagestan State University; sigab.ru@yandex.ru}

The collection of documents "The Muslim Community of the Caucasus in the Georgian Archival Documents. 1800-1917" by Gela Guniava includes dozens of reports covering the activities of Islamic institutions in the Caucasus and the relationships of the tsarist colonial administration with the "official" clergy. The collection is of great interest to Islamic scholars,

\footnotetext{
${ }^{1}$ Иманутдин Хабибович Сулаев - доктор исторических наук, доцент кафедры отечественной истории исторического факультета Дагестанского государственного университета.

${ }^{2}$ Imanutdin Khabibovich Sulaev - Doctor of Sc. (History), associate professor at the Department of Russian History, the Faculty of History, Dagestan State University.
} 
theologians, historians, political scientists and other researchers, as well as to non-specialist audiences.

Keywords: Transcaucasian Sunni and Shi'a general boards, the Governor of the Caucasus, Islam, mosque.

После распада СССР интерес к вопросам взаимоотношений государства и религий у учёных бывших республик Советского Союза резко возрос, что можно объяснить, в частности, доступностью ранее закрытых архивных фондов, появлением свободы выбора методов и форм изложения, отсутствием цензуры на интерпретацию документов и т. д. Соответственно в 90-е гг. прошлого и в начале нынешнего века появились десятки научных работ, посвящённых этой проблеме.

Распад Советского Союза привёл не только к экономической дезинтеграции бывших советских республик, но и к ослаблению научных связей между их научными сообществами. Несмотря на многочисленные проблемы экономического порядка, а именно: отсутствие поддержки научных изысканий со стороны государства, российские учёные находили и находят возможность выезжать в страны ближнего и дальнего зарубежья с научно-исследовательскими целями. Когда я ездил работать в грузинских архивах, сотрудники Национального архива Грузии предложили мне сборник документов, подготовленный гражданином их страны, исследователем Гела Гуниава. После состоялось наше знакомство, и он подарил мне два экземпляра своего труда (Исламская община Кавказа по документам Грузинских архивов 1800-1917 гг. / сост. Гела Гуниава. - г. Кум (Иран), 2013).

Ислам является одной из традиционных религий на территории России. Непрерывное расширение территории России в XVI-XIX вв., включение в её состав Поволжья, Приуралья, Сибири, Крыма, Кавказа, Туркестана сделали русскоподданными многочисленные народы, которые исповедовали ислам. Политика веротерпимости по отношению к мусульманам империи была провозглашена императрицей Екатериной II, и это была дальновидная политика, которая имела больше преимуществ, чем недостатков. К концу XIX в. 14миллионная мусульманская община сделалась второй по численности после общин православных вероисповеданий группой населения Российской империи [1, с. 3].

Главным принципом конфессиональной политики Российской империи было стремление к полному государственному контролю над всеми без исключения религиозными институтами на территории страны, поэтому для надзора над жизнью российского мусульманства правительство Екатерины II создало органы управления в форме Духовных правлений. В 1788 году было создано Оренбургское магометанское духовное собрание, в юрисдикции которого вначале находились все исламские институты России. В 1831 году было учреждено Таврическое магометанское духовное правление для мусульман Крыма, а в 1872 году было учреждено Закавказское мусульманское духовное правление шиитского и суннитского учений $[1$, с. 20, 23].

Сборник документов, подготовленный Гела Гуниава, состоит из введения на русском (с. 10-13), грузинском (с. 14-18) и турецком (с. 19-22) языках, административной карты Кавказского края начала XX века (с. 23), изданной редакцией Кавказского календаря. Затем идут XIII глав: I глава называется «Положения и инструкции по управлению Закавказского мусульманского духовенства» (с. 24-146); II - «Отчёты мусульманских духовных правлений» (c. 147215); III - «Руководители мусульманского духовенства и кадровые перестановки» (с. 216-292); IV - «Жалобы и разбирательства дел» (с. 293-326); V - «Финансовые 
Sulaev I.Kh. Gela Guniava. Gela Guniava. The Muslim Community of the Caucasus in the Georgian Archival Docu-ments. Years 1800-1917: a Collection of Documents. - The City of Qom (Republic of Iran). - 2013. 600 pp. // Islamovedenie. 2017. V. 8. № 2. P. 106-118

вопросы» (с. 327-356); VI - «Культовые помещения» (с. 357-370); VII «Мусульманские учебные заведения» (с. 371-437); VIII - «Изучение настроения мусульманского населения» (с. 438-484); IX - «О религиозных притеснениях» (с. 485-534); Х. «О сектантах» (с. 535-547); XI - «О проблемах выезда мусульманских паломников в святые места» (с. 548-561); XII - «О переселении мусульманского населения в Османскую империю» (с. 562-578); XIII - «Статистические сведения» (c. 579-597).

Первая глава сборника «Положения и инструкции по управлению Закавказского мусульманского духовенства» включает 8 различных проектов, положений и инструкций. Первым в сборнике даётся «Проект положения Закавказского мусульманского духовенства» (с. 24-146), согласно журналу Совета Главного управления наместника Кавказа датируемый 7, 11, 12, 13, 18 и 19 ноября 1869 года (c. 24-38). «Проект положения...» был плодом долгих «частных совещаний» Совета Главного управления наместника Кавказа. В обсуждении «Проекта» принимали участие все высшие чины наместничества Кавказа (их было 7) и приглашённые военные губернаторы: Бакинский, Тифлисский, Елисаветпольский и начальник Кавказского горского управления. Председательствовал на совещаниях начальник Главного управления наместника Кавказа, сенатор, статс-секретарь, тайный советник барон Александр Павлович Николаи. Протокол своими подписями заверили 11 чиновников плюс правитель (начальник) канцелярии и делопроизводитель.

«Положение об управлении Закавказского мусульманского духовенства шиитского учения» от 5 апреля 1872 г. в сборнике приводится на русском языке (с. 39-61), а на азербайджанском языке арабским шрифтом напечатаны фотографии «Положения»

(c. 62-89). Согласно «Положению», в сословие «высшего и приходского (мечетского)» шиитского духовенства включены шейх-уль-ислам, казии и муллы с указанием состава и устройства управления, прописаны условия вступления мусульманских духовных лиц в должности. Прежде всего претендент должен был

быть подданным Российского государства, выдержать испытания в «соответствующих для каждого духовного звания познаниях» и получить подтверждающее свидетельство (с. 41). Для занятия высших духовных должностей были введены возрастные ограничения, претендент должен был быть старше 22 лет.

Высший надзор за Духовными управлениями шиитского и суннитского учений и мусульманским духовенством возлагался на наместника Кавказа (с. 39). Зарегистрированных мусульманских духовных лиц царские чиновники на Кавказе называли «штатными» (с. 423), а в современной исторической литературе принято называть их «указными» или «официальным духовенством». Для обозначения зарегистрированного властями мусульманского духовенства от шейх-уль-ислама и муфтия до кадиев и мулл мы будем использовать название «официальное мусульманское духовенство».

Аналогичное «Положение» было издано и для «управления Закавказского мусульманского духовенства суннитского учения» (с. 90-109). Духовный глава суннитов носил звание муфтия, а другие категории духовенства назывались так же, как и у шиитов, - казии (члены Духовных управлений и Меджлисов) и приходские (мечетские) муллы.

Далее в первую главу сборника Гела Гуниава включены «Проект инструкции Закавказскому муфтию по управлению магометанским духовенством “Омарова учения"», утверждённый генерал-адъютантом князем Орбелиани 15 марта 1863 года (c. 114-138), и «Инструкция о порядке испытания на вступление в мусульманское духовенство» 
(c. 139-146), утвержденная 11 июня 1873 года наместником Кавказа князем Михаилом Николаевичем (в документе военное звание наместника записано как «генерал-фельдцейхмейстер «Михаил»). Эта «Инструкция...» от 11 июня 1873 года отложилась в единственных экземплярах и в фондах Центрального государственного архива Республики Дагестан (ЦГА РД, ф. 126, оп. 2, д. 14, л. 28-30 об.), и в Государственном историческом архиве Азербайджанской Республики [2]. Автор этой рецензии сверил статьи «Инструкции...» и убедился, что это копии одного документа. Как следует из «Инструкции...», последователей «вредных учений», каковыми считались «шейхизм» и «зикризм» (последователи суфизма), власти не только не утверждали в должностях «указных» мулл и кадиев, им ограничивался даже выезд в Турцию или Иран для получения образования или для пополнения своих знаний. Данный запрет распространялся как на суннитов, среди которых было больше последователей суфизма, так и на шиитов. В официальных документах кавказского наместничества и в переписке русских военных и чиновников суфизм чаще называют запрещённым течением ислама - «мюридизмом» и «зикризмом». Суфиев преследовали как сторонников радикального ислама и противников русской власти на Кавказе. Как показывают другие источники, после Кавказской войны (1817-1864) в антиколониальных восстаниях, которые имели место на Кавказе и в частности в Дагестанской области, участвовали не только последователи суфизма, но и представители зарегистрированного, или «официального», «указного» духовенства.

Торжественное открытие в Тифлисе Закавказских мусульманских духовных правлений шиитского и суннитского учений состоялось 2 января 1873 года. На открытии присутствовали почётные гости от царской администрации на Кавказе и мусульманской общины шиитов и суннитов. После прочтения указов об учреждении Закавказских духовных правлений от 5 апреля 1872 года и ознакомления с расписанием должностей духовных правлений глава шиитов Закавказья шейх-ульислам, глава суннитов (муфтий) и члены духовных правлений дали присягу на верность государю императору, а затем была совершена молитва о здравии и благоденствии государя императора и его семьи. Эти торжества были освещены газетой «Кавказ», выходившей в Тифлисе (с. 110-111).

Вторая глава сборника представлена отчётами Закавказского Суннитского Мусульманского Духовного правления за 1892 г. и Закавказского Шиитского Мусульманского Духовного правления за 1899 г., молитвами за царя, разосланными в 1843 году генералом Ермоловым для чтения в мечетях мусульманским духовенством, и молитвой Закавказского муфтия Г.Э. Гаибова за царя, утверждённой заместителем министра народного просвещения 25 июня 1901 г. Отчёты Закавказских духовных правлений интересны не только тем, что содержат статистические данные о количестве «указного», «официального» мусульманского духовенства в Закавказье, о составе и количестве «вакуфных сумм», но и тем, что отражают деятельность Духовных правлений суннитов и шиитов за год в разных областях (с. 147-165; 182-215).

Третья глава сборника содержит списки руководителей Закавказского духовного правления шиитов и суннитов с 1846 по 1917 годы и других служителей мусульманского культа по губерниям и уездам (с. 216-227). Для исследователей ислама и исламской общины Закавказья будут интересны и указы о назначении представителей «официального» мусульманского духовенства, заявления-прошения от претендентов на духовные должности, их переписка с властями (с. 228-292). 
Sulaev I.Kh. Gela Guniava. Gela Guniava. The Muslim Community of the Caucasus in the Georgian Archival Docu-ments. Years 1800-1917: a Collection of Documents. - The City of Qom (Republic of Iran). - 2013. 600 pp. // Islamovedenie. 2017. V. 8. № 2. P. 106-118

Четвёртая глава сборника посвящена разъяснениям и толкованиям разных случаев суда по шариату, жалобам и разбирательству в судах бракоразводных дел и других спорных вопросов (с. 293-326).

По мере завоевания и подчинения мусульманского Кавказа царская администрация утверждала в должности выбранных обществами духовных лиц, а в исключительных случаях - назначала их без выборов. Как показывают материалы настоящего сборника документов, представители «официального» мусульманского духовенства в Закавказье получали жалованье с 1805 года (с. 349), ещё задолго до учреждения Закавказских духовных правлений. Так, в 1805 году на содержание мусульманского духовенства Елисаветпольской области из Грузино-Имеретинской казённой палаты выделялось 1300 рублей серебром. Эта же сумма на содержание «официального» духовенства сохранилась и в 1844 году. Так, ахунд (кадий) Елисаветпольского округа получал 500 рублей, а рядовые муллы - по 100 рублей (с. 329).

По представлению наместника Кавказа государь император Александр II назначил 8-го июля 1856 года муфтию суннитов Закавказья 1600 рублей серебром в год, включая квартирные и премиальные (с. 352). Должностной оклад главы шиитов шейх-уль-ислама в 1872 году тоже соответствовал окладу муфтия - 1600 рублей (с. 59), члены правления получали 600 рублей, писцы - 500 рублей, члены губернских меджлисов (кадии) получали по 300 рублей. Всего на ежегодное содержание Закавказского мусульманского духовенства шиитского учения выделялось 20740 рублей (с. 61). На содержание рядовых служителей тратилось намного меньше. Например, муэдзин Тифлисской мечети с 1-го января 1867 года по 1-е января 1869 года получил

всего 300 рублей (с. 356). При этом царская администрация на Кавказе требовала от официального духовенства строгого учёта финансов и отчёта об их расходовании (с. 356).

Вопросы финансирования Закавказских духовных правлений (Гела Гуниава назвал их «Финансовые вопросы») вошли в пятую главу сборника (с. 327-356), хотя несколько документов финансового характера содержатся в первой главе (с. 59-61). Как свидетельствуют документы пятой главы, создание «официального» мусульманского духовенства в Закавказье и назначение некоторым из них зарплаты стимулировало невежественных и малообразованных духовных лиц на улучшение и пополнение качества своих знаний и обязанностей.

Проблемы, связанные с содержанием и эксплуатацией культовых зданий (мечетей), и споры мусульманских общин по поводу мечетских (вакуфных) земель, переписка Духовных правлений шиитов и суннитов с наместником Кавказа с просьбами и ходатайствами по вопросам ремонта старых и постройки новых мечетей включены в шестую главу сборника (с. 357-370). Хронологические рамки материалов, включённых в шестую главу, охватывают 1863-1914 гг.

По мере утверждения российской колониальной власти на Кавказе ею открывались учебные заведения для детей мусульман. Например, в 1838 г. в городе Дербенте было открыто 3-классное уездное училище, в 1847 году было открыто 3классное мусульманское училище в городе Тифлисе для детей шиитов (с. 373-387), училище для детей суннитов города Тифлиса было открыто в январе 1849 года (с. 387), в 1855 году мусульманские училища на частные добровольные пожертвования были открыты в Ленкорани и Сальянах (с. 400). Учебные программы училищ, хозяйство, штаты, сметы и все другие вопросы утверждал Наместник Кавказа «по его ближайшему усмотрению» (с. 375). На содержание Тифлисского мусульманского училища «Омарова учения» в мае 1848 года было отпущено 1305 рублей, причём штат и сумму на его содержание собственноручно заверил государь император 
Николай I, а потом этот документ заверили подписями другие высокопоставленные чины империи (с. 389).

Училища открывались и для девочек-мусульманок, причём инициативу в некоторых случаях проявляли сами главы Закавказских духовных правлений шиитов и суннитов (с. 421-423). В настоящий сборник документов включены обращения глав Духовных правлений шиитов и суннитов к ахундам и кадиям. Как и все другие официальные документы, обращения глав Духовных правлений санкционировались царской администрацией. В этих обращениях обосновывается необходимость получения образования не только мальчиками, но и девочками. Например, в своём обращении «во все шиитские губернские меджлисы» шейх-уль-ислам Закавказского духовного правления шиитов (не позже января 1896 года) обосновывает ценность и важность получения образования мусульманскими детьми. Свои доводы он подкрепляет примером получения глубоких знаний мусульманским философом Ибн Синой (Авиценной) и его матерью Ситарой (с. 425). В предполагаемом к открытию «закрытом женском училище» девочки должны были обучаться мусульманскому вероучению, в «сокращённом виде - истории и географии России, черчению, рисованию и рукоделию». Правда, для женского училища требовалось построить помещение, для чего «единовременно требовалось 50000 рублей и 15000 рублей ежегодно на текущие расходы». Для этого привлекались частные пожертвования (с. 426).

Аналогичное обращение по санкции властей к суннитским кадиям с призывом помочь собрать пожертвования для создания «закрытого женского училища» под названием «циркулярное предписание» 27 ноября 1895 года подготовил и муфтий Духовного правления суннитов Г.Э. Гаибов (с. 427-431). Вскоре от частных лиц и мусульманских обществ стали поступать пожертвования. Военный губернатор Дагестанской области 10 июня 1896 года сообщал Главноначальствующему гражданской частью на Кавказе о том, что после объявления населению Дагестанской области «циркулярного предписания» муфтия «незначительное число лиц из туземного населения изъявило согласие сделать пожертвования» (с. 431). Дагестанская область относилась к Закавказью, соответственно все религиозные учреждения, находящиеся на её территории, были подведомственны Закавказским духовным правлениям шиитов и суннитов.

Эриванский губернатор 18 ноября 1896 года сообщал в администрацию на Кавказе о том, что на открытие в Тифлисе учебного заведения для мусульманок внесено «единовременно 1186 руб. 55 коп. и ежегодно планируется вносить по 169 рублей» (с. 433). Елисаветпольский губернатор 27 января 1897 года сообщал о том, что пожертвований на это дело собрали только в сумме 60 рублей 57 копеек (c. 434). Такие мизерные суммы пожертвований для открытия в Тифлисе женского мусульманского училища от мусульман Кавказа можно объяснить не только бедностью населения, но и тем, что многие из кавказских мусульман были против развития женского образования. Тем не менее, в конце XIX и особенно в 10-20-е гг. $\mathrm{XX}$ в. на мусульманском Кавказе функционировало некоторое количество мектебов и медресе, где обучали и девочек.

Царская администрация требовала установления административного и полицейского надзора за всеми учебными заведениями мусульманского Кавказа, в том числе и за примечетскими (мектебы и медресе) (с. 413-415), открытыми самими обществами. Открытие на Кавказе учебных заведений, подконтрольных царской администрации, объясняется её заинтересованностью в ускоренной адаптации кавказских мусульман к российскому правовому и культурному пространству, а также необходимостью подготовки чиновников из местных жителей для службы в 
Sulaev I.Kh. Gela Guniava. Gela Guniava. The Muslim Community of the Caucasus in the Georgian Archival Docu-ments. Years 1800-1917: a Collection of Documents. - The City of Qom (Republic of Iran). - 2013. 600 pp. // Islamovedenie. 2017. V. 8. № 2. Р. 106-118

администрациях. Переписка царской администрации на Кавказе с Духовными правлениями шиитов и суннитов, связанная с учреждением и открытием учебных заведений для детей мусульман Закавказья, уставы для училищ, смета и штаты для них включены в седьмую главу сборника (с. 371-437).

В седьмую главу сборника попало и ходатайство исполняющего обязанности члена Духовного правления суннитского учения Гаджи Саида Эфенди Унеи-заде наместнику Кавказа от 5-6 декабря 1878 года о разрешении издания с 1-го января 1879 года еженедельной газеты на азербайджанском языке под названием «Сияние» (c. 435-436). Ходатайство было удовлетворено, и начальник Главного управления наместника Кавказа сообщал исполняющему обязанности Тифлисского губернатора о том, что газета стала издаваться с 1 января 1879 года, как и планировалось. Теперь администрация наместника выясняла у губернатора Тифлиса, не сможет ли тот помочь в распространении и в доставке газеты для сельских жителей, и просила его содействия (с. 437). Для доставки газеты сельским мусульманам услуг почтовых отделений было недостаточно, так как их было мало. Здесь от губернатора Тифлиса требовалось помочь в доставке газеты «всадниками земской стражи или сельских старшин» (с. 437).

Чтобы управлять колониями, российской администрации требовались не только сильная армия и верное, подготовленное чиновничество, но и обратная связь с местным населением. Для своевременного выяснения политических и оппозиционных настроений у кавказских мусульман царскому режиму необходима была точная информация из достоверных источников. Такими доверенными информаторами для российской колониальной администрации на Кавказе стали представители официального духовенства в лице глав Духовных правлений - шейхуль-ислам и муфтий, члены правлений и многочисленные ахунды и кадии на местах.

В восьмую главу сборника, которую автор Гела Гуниава назвал «Изучение настроения мусульманского населения», включены донесения и доклады, «секретные записки», рапорты шейх-уль-ислама и муфтия наместникам и другим высокопоставленным чинам царской администрации на Кавказе (с. 438-484). Восьмую главу сборника открывает «записка» муфтия Закавказского края от 18 декабря 1859 года начальнику Главного управления наместника Кавказа, действительному статскому советнику и кавалеру А.Ф. Крузенштерну (с. 438-441). Как российский верноподданный муфтий сообщает Крузенштерну о «вредных действиях мусульманского духовенства», препятствующих сближению мусульманского населения с «духом русского управления» и возбуждающих «ненависть к русской нации и вообще к иноверцам». В числе антироссийски настроенных духовных лиц муфтий называет Гаджи Исмаила Эфенди Гаджи Ахмед Эфендия, Гаджи Махмуда и Гасана Эфенди в Шемахинской губернии, муллу Садыха в Ордубадском уезде, муллу Мамада и Кази-Магомеда в Кюринском ханстве, Гамзата (Гамзат-бека) и Шамиля в Дагестане, которые, «приобретя сильное влияние на умы народа», «своими проповедями оттолкнули мусульманский народ на отдалённое расстояние от русского в то самое время, когда он только что начал привыкать к русскому управлению и понимать русские законы» (с. 438).

В конце «записки» муфтий предлагает меры, включающие семь пунктов, которые, по его мнению, должны сгладить отношения между мусульманской оппозицией и царским режимом на Кавказе. В их числе он предлагает: 1. «Учредить порядок наподобие для армянского и грузинского духовенства; 2. Подчинить всех духовных лиц одному духовному начальнику; 3. Запретить духовенству присваивать произвольно духовное звание без разрешения властей; 4. Ограничить число духовных лиц по мере надобности; 5. Поставить все частные училища на учёт, и обязать учителей без разрешения главного духовного начальства не заниматься 
воспитанием студентов и отчитываться ежегодно об успехах своих студентов; 6 . Назначить небольшое жалованье этим учителям, равно как кадиям, в городах и в пограничных пунктах; 7. Передать все мечетские доходы в ведение Главного духовного начальства, чтобы из этих доходов по представлению начальства награждали отличившихся в усердии духовных лиц и студентов» (с. 440-441).

В своём «Наставлении» Закавказский муфтий Мамед Эфенди Муфти-заде призывал мусульман-суннитов и духовных лиц к послушанию и верности русской власти. Такие же идеи изложены и в «Благодарственной молитве» муфтия, адресованной царю и его семье (с. 453-458). Два последних документа не датированы.

На умонастроения мусульман Кавказа, конечно же, оказывали влияние русскотурецкие войны XIX века. Тому свидетельство опубликованная в сборнике секретная записка начальника Ставропольского губернского жандармского управления от 4 мая 1877 года, адресованная «Императорскому Высочеству». В ней докладывалось об усиливавшихся антироссийских настроениях среди мусульман Терской области и их сочувствии туркам-единоверцам в связи с военной кампанией 1877-1878 годов на Балканском полуострове. Здесь же сообщалось и о прокламациях, которые тайно среди горцев ещё в 1876 году распространяли турецкие эмиссары. Эмиссары проникали на мусульманский Кавказ под видом добровольцев-мусульман, собиравших денежные средства «для своих бедных родственников в Мекке». В прокламациях, доставленных эмиссарами и распространяемых в населённых пунктах, горцев-мусульман призывали к восстанию против русского правительства. Нередко распространять прокламации эмиссарам помогали представители «официального» духовенства, которые зачитывали их содержание в мечетях во время молебнов. И как сообщалось в докладе, в результате агитации турецких эмиссаров в Чечне вспыхнуло восстание, руководимое Алибеком и Султан Мурадом. Последние собрали «толпу вооружённых горцев и, разъезжая с ними по аулам, призывали всех присоединиться к ним». Как докладывал начальник жандармского управления, 27-29 апреля 1877 года восставшие горцы напали на русский гарнизон, но получили отпор и были рассеяны, а повстанцы скрылись в горах. «Восстание как будто утихло, но нельзя сказать, что оно совершенно прекращено», - неопределённо завершает он свой доклад (с. 458-459).

О том, что мусульмане города Баку и Бакинской губернии слабо заражены революционными идеями и об армяно-азербайджанских столкновениях, панисламистских и пантюркских настроениях среди мусульман Закавказья, усилившихся в начале XX в., свидетельствует доклад от 9-го марта 1912 года, подготовленный особым отделом канцелярии наместника Кавказа на имя помощника по гражданской части наместника Кавказа (с. 461-484). Судя по содержанию, доклад является обобщением разных секретных материалов, собранных российскими охранительными и секретными службами на всем Кавказе почти за десять лет.

Особый интерес представляет первая часть доклада, составленная из отчёта сенатора Кузьминского, подготовленного им по итогам «ревизии города Баку и Бакинской губернии» в 1902-1905 гг. По мнению Кузьминского, мусульман в революционную деятельность пытались вовлечь именно армяне, но безуспешно. Сенатор усмотрел в этом твёрдое осознание мусульманами «верноподданнического долга» перед государем и объяснял это догматами ислама, но он выражал сомнение в том, что мусульманская масса и в дальнейшем «останется мало восприимчивой к идеям социализма и различных политических течений» (с. 462). 
Sulaev I.Kh. Gela Guniava. Gela Guniava. The Muslim Community of the Caucasus in the Georgian Archival Docu-ments. Years 1800-1917: a Collection of Documents. - The City of Qom (Republic of Iran). - 2013. 600 pp. // Islamovedenie. 2017. V. 8. № 2. P. 106-118

Во время встречи с наместником Кавказа 10 июня 1905 г. депутация от мусульман заявила ему о том, что причинами армяно-азербайджанских противоречий и столкновений в начале XX века в Баку были неравноправные условия, созданные царской администрацией для христиан-армян и мусульманазербайджанцев (с. 463).

Распространение панисламизма среди российских мусульман авторы доклада объясняют пропагандой турецких эмиссаров. Эмиссары доставляли в Закавказье прокламации «возмутительного содержания», в которых призывали мусульманское духовенство содействовать восстанию российских мусульман в защиту ислама и Персии, которым будто бы угрожает опасность со стороны европейских держав (с. 468).

Одновременно в насаждении панисламистских идей власти обвиняли мусульманскую печать Кавказа и создателей Всероссийского мусульманского союза (1906 г.), устав которого подготовил присяжный поверенный азербайджанец Топчибашев

(c. 468). Власти не усмотрели «никаких проявлений панисламизма» в Черноморской, Кутаисской, Тифлисской, Эриванской и Бакинской губерниях, Кубанской и Карской областях, Сухумском и Закатальском округах (с. 469). Наиболее подверженными идеям панисламизма власти посчитали Батумскую область (с. 469-471), Дагестанскую область (с. 471-483) и Бакинское градоначальство (с. 483-484). Мусульман Батумской области считали приверженцами панисламизма и пантюркизма, т. к. эта область в недавнем прошлом была составной частью Турции, и эти идеи для них «не есть какое-либо наносное явление, которое нуждается в поддержке и развитии; то и другое здесь вполне естественно и входит в миросозерцание местного населения» (с. 470).

Как следует из доклада, распространение панисламизма и пантюркизма нашло благодатную почву среди мусульман Дагестанской области, наиболее «фанатичных» и подверженных влиянию ислама и потому поднявшихся на восстание в 1877-1878 годах, в разгар русско-турецкой войны. Общее мнение русских военных и служащих в Дагестане сводилось к тому, что «туземцы Дагестана не заслуживают оказываемого им администрацией безграничного доверия», т. к. при осложнении российско-турецких отношений дагестанцы всегда выступали союзниками турокединоверцев (с. 473).

Российские власти внимательно отслеживали перемещение турецких эмиссаров по сёлам Дагестанской области и Чечне, соответственно были информированы об их встречах с видными религиозными деятелями, о перемещениях дагестанских мухаджиров на Родину и обратно в Турцию. В докладе, например, сообщалось о том, что турецкие эмиссары были в аварских аулах и встречались в 1909-1910 гг. с суфийским шейхом Узуном-хаджи Салтинским и другими религиозными деятелями (c. 474-475).

Доклад Особого отдела наместника Кавказа содержит очень ценный для специалистов материал о численности мюридов различных шейхов Дагестана, росте числа паломников из Дагестанской области в начале XX века и т. д. Как сообщалось в докладе, у шейха Узун-хаджи Салтинского из Гунибского округа было более 3000 последователей как в Дагестане, так и в Чечне, которые имели с ним постоянное общение (с. 474). Отмечается также, что «в каждом округе Дагестанской области существуют по одному или по нескольку тарикатских шейхов, имевших по 30004000 и более последователей называемых мюридами» [с. 474-475]. Как сообщается в докладе, общее число паломников в 1911 году из Дагестанской области составило 900-1000 человек на 660 тысяч жителей. Увеличение числа паломников на 400 человек по сравнению с прошлым годом власти объясняли тем, что губернатор 
области находился в отпуске и не мог уговорить мусульман не совершать паломничество (с. 477), как это он делал раньше. К сожалению, часть материала о паломничестве и мусульманском движении включена в десятую и одиннадцатую главы сборника, что затрудняет анализ материалов сборника по главам.

Настоящий доклад, составленный Особым отделом наместника Кавказа 9 марта 1912 года, представляет большую ценность как источник, содержащий немало информации об учебных заведениях, открытых царским правительством в Дагестанской области, и об отношении власти и к зарождающейся дагестанской интеллигенции. Мы полагаем, что некоторые сведения, содержащиеся в докладе, ещё не введены в научный оборот и будут интересны для исследователей.

В Российской империи существовало не только национальное, но и конфессиональное неравноправие. В девятую главу сборника вошли документы, которые могут стать важным источником для изучения неравноправных конфессиональных отношений в империи. В частности, ещё в 1848 году наместник Кавказа князь М.С. Воронцов запрещал христианам обращаться в ислам или «единожды получившему крещение обратиться в мусульманство» (с. 489). Последнее касалось ингушей, принявших православие в силу различных причин, а затем пожелавших вернуться в ислам. Такое отступничество было объявлено «величайшим преступлением». На распоряжение военного министра империи князя Чернышева от 21 июня 1842 года Главноуправляющий Грузии, опираясь на доклад экзарха Грузии, сообщал, что ингуши выгнали всех священников и, «за исключением одного Базоркина, в 1843 году совратились в магометанство» (с. 492493).

В девятую главу включены также ходатайства глав армяно-григорианской церкви наместнику Кавказа (1853-1873 гг.) с просьбой разрешить им принять «магометан в христианскую веру» (с. 494-499, 503), переписка Главного управления наместника Кавказа с экзархом Грузии о проблемах, возникших в связи с отказом от христианской веры ингилойцев Закатальского округа и желанием их вернуться в ислам (с. 509-524), переписка между Кавказской и Тифлисской городской администрациями по вопросам запрещения городской торговли купцам и ремесленникам мусульманского вероисповедания в воскресные дни (с. 504-508).

В целях сохранения позиций православия по действующим российским законам запрещались браки православных с нехристианами, брачующиеся нехристиане должны были принять православие. Но были случаи, когда христиане женились на мусульманках или христианки выходили замуж за мусульман и те принимали ислам. При выявлении таких браков власть старалась обязательно расторгнуть их.

У исследователей вызовет интерес также переписка дворянки города Алексин Тульской губернии Авдотьи Щукиной с верховной властью империи. Она вышла замуж за новообращённого христианина из Геокчайского уезда Бакинской губернии Молла Гамид Гаджи Джабраил-оглы, заключённого в тюрьму 13 января 1875 года за «разбои, оскорбление действием караульного солдата и поношение православной веры» и высланного за это в Тульскую губернию под надзор полиции (с. 527-529). Здесь он принял православие и получил от священника имя Алексея Щукина. Надо полагать, что в ссылке он заключил «брак по расчёту» и женился на Авдотье Щукиной, которая дала ему свою фамилию. Авдотья Щукина написала ходатайство министру внутренних дел империи, а освобождение из тюрьмы новообращённый христианин, её муж, получил по указу Государя императора Александра II.

Свидетельством того, что православие пользовалось покровительством царской администрации на Кавказе, служат запреты мусульманам на пропаганду исламских ценностей среди православных и вовлечение последних в ислам (с. 534). Власти 
Sulaev I.Kh. Gela Guniava. Gela Guniava. The Muslim Community of the Caucasus in the Georgian Archival Docu-ments. Years 1800-1917: a Collection of Documents. - The City of Qom (Republic of Iran). - 2013. 600 pp. // Islamovedenie. 2017. V. 8. № 2. P. 106-118

всячески пресекали такого рода случаи. В главе приводится список мусульман, проживающих в сёлах Гудаутского, Кодорского и Гумистинского участков, Сухумского округа, «замеченных в пропаганде ислама среди православных» и соответственно действующих во вред православию (с. 531-533). Кутаисский военный губернатор по военно-народному управлению в своём докладе директору канцелярии Главноначальствующего гражданской частью на Кавказе 23 февраля 1899 года рекомендовал 11 мусульман, замеченных в пропаганде ислама, выслать во внутренние губернии империи, 32 лицам «сделать предостережение» о том что, если кто-нибудь из них будет замечен в противозаконных действиях во вред православию, будет выслан немедленно», за 9 лицами нарушений не было замечено, и было рекомендовано не привлекать их к ответственности (с. 530). Гела Гуниава дал девятой главе название «О религиозных притеснениях», что в целом соответствует содержанию 13 документов, вошедших в главу.

Свидетельством роста популярности суфизма среди мусульман Кавказа (власти больше использовали слова «тарикат», «мюридизм» и «зикризм») накануне и особенно после Кавказской войны служат доклады, записки и рапорты глав Духовных правлений Закавказья шиитского и суннитского учений царской администрации, вошедшие в десятую главу сборника (с. 535-547).

Обстоятельный анализ распространения суфизма в Нухинском, Шемахинском, Кубинском уездах и «в разных частях Дагестана» дан в секретной записке шейх-ульислама Закавказья 18 декабря 1863 года в адрес начальника главного управления наместника Кавказа, сенатора, статс-секретаря и барона А.П. Николаи (с. 537-542) и в «доносе» властям жителя Нухинского уезда Арешского участка деревни Караган Шихлар Сеида Адулла Эфенди Сеид Дадаш-оглы от 18 ноября 1872 года (с. 543545).

Как правило, особо активных суфиев власти высылали во внутренние губернии империи или в Сибирь. В частности, военный губернатор Дагестанской области в своём докладе в адрес Главноначальствующего на Кавказе от 19 сентября 1889 года рекомендовал жителя селения Чаях Казикумухского округа Магомеда Магомедоглы, «по характеру и фанатизму уступающего лишь главному из деятелей этого учения жителю селения Кикуни Магомеду Гаджи Осман-оглы», выслать «в отдалённые места Сибири навсегда» (с. 546). Как следует из переписки кавказской администрации в адрес МВД империи, житель селения Чаях, «замеченный в распространении среди населения Дагестана мусульманского учения «тарикат», должен был отправиться в город Астрахань для дальнейшего сопровождения в Сибирь (с. 547).

К проблеме паломничества российских мусульман в Мекку военные и чиновники империи относились по-разному. В целом в высших кругах империи возобладал прагматичный подход, и в течение XIX - начала XX века постепенно решалось множество проблем юридического, экономического, медицинского и транспортного характера. Во второй половине XIX века мусульманам, желающим совершить паломничество, выдавались загранпаспорта, а на рубеже XIX-XX вв. российских паломников доставляли на специальных судах по Чёрному и Каспийскому морям до определённого места. Паломников стали сопровождать врачи, а на государственных границах и в местах накопления для паломников устанавливались специально оборудованные врачебно-наблюдательные пункты, где они проверялись на наличие заболеваний Ђ (с. 557, 560-561).

Материалы сборника Гела Гуниава показывают, что паломничество для российских мусульман стоило дорого, расходы одного паломника в Мекку составляли от до 300 руб. Шииты-паломники могли поехать в Кербелу за половину этой суммы, а в 
Мешед - за 40-50 руб. [с. 549]. Паломники, которые были замечены в нарушениях российских законов, могли быть лишены возможности повторной поездки в хадж или понести административное наказание [c. 556-558]. Власти каждый год выявляли такие нарушения. Частыми были случаи нелегального паломничества как среди суннитов, так и среди шиитов Кавказа, о чём Эриванский губернатор 7 июля 1903 г. докладывал директору канцелярии Главноначальствующего гражданской частью на Кавказе (с. 559).

Во время и после Кавказской войны (1817-1864) кавказские мусульмане стали переселяться в Турцию, особенно много было мухаджиров-переселенцев из Западного Кавказа. Документы по вопросам переселения (мухаджирства) мусульман вошли в двенадцатую главу сборника (с. 562-578). Особый интерес представляют списки мусульман из Тифлисской губернии (с. 562-566), семейные списки мусульман селения Болниси-Капанакчи этой же губернии (с. 567-569), обращения отдельных мусульман из Дагестанской области и Нухинского уезда (c. 572-574) к властям о выдаче разрешения на выезд в Турцию.

В двенадцатую главу вошла также небольшая переписка Министерства иностранных дел Российской империи, турецких властей и дипломатов по вопросам переселения в Турцию семей и отдельных лиц (с. 575-578). В частности, турецкий посол в Санкт-Петербурге «по приказанию своего правительства» передал в Министерство иностранных дел России ходатайство 70 семейств из Кубинского уезда Бакинской губернии о разрешении им переселиться в Турцию (с. 578). Как правило, российские власти не препятствовали мусульманам, желающим переселиться в единоверную Турцию.

Сборник документов Гела Гуниава завершают статистические сведения о числе мечетей и служителей мусульманского культа в Закавказье, предоставленные властям главами Духовных правлений шиитского и суннитского учений (с. 580-593). Особый интерес у исламоведов могут вызвать сведения о мечетях и количестве их обслуживающих мулл в Тифлисской, Елисаветпольской, Бакинской и Эриванской губерниях (с. 580-581), Дагестанской области (c. 583, 587), Батумском и Артвинском округах (с. 584), Карсской области (с. 586), которые датируются 1 января 1889 г. Отдельно даются списки молитвенных зданий и «официального» духовенства шиитов Закавказья за 1913 год (с. 592-593).

В содержании сборника автор указал всего 93 документа и материала, но документов дано намного больше. Например, в седьмую главу включен документ под общим названием «Об учреждении в Тифлисе женского мусульманского училища» (с. 416-437), а на самом деле вопросу учреждения данного учебного заведения посвящено пятнадцать документов. В частности, сюда вошли: письмо из канцелярии Министерства народного просвещения империи попечителю Кавказского учебного округа от 31 июля 1895 года (с. 416-420), «копия с отзыва министра народного просвещения Главноначальствующему гражданской части на Кавказе» от 22 ноября 1883 года (с. 421-422) «из дела канцелярии попечителя Кавказского учебного округа за 1880 год под № 209 относительно учреждения в г. Тифлисе женского мусульманского училища» (с. 422-423), два письма от канцелярии Главноначальствующего Закавказскому шейх-уль-исламу и муфтию от 18 ноября 1895 года с просьбой посодействовать «привлечению штатных» мусульман-шиитов и суннитов «К пожертвованиям для образования особого капитала с целью учреждения упомянутого училища» (c. 423-424) и т. д. Здесь же нарушен хронологический принцип изложения документов. Такая небрежность в подаче документов и материалов допущена почти в каждой главе сборника. 
Sulaev I.Kh. Gela Guniava. Gela Guniava. The Muslim Community of the Caucasus in the Georgian Archival Docu-ments. Years 1800-1917: a Collection of Documents. - The City of Qom (Republic of Iran). - 2013. 600 pp. // Islamovedenie. 2017. V. 8. № 2. Р. 106-118

К сожалению, ни один документ автор сборника не сопровождает комментариями и разъяснениями, не даёт он и биографических данных упоминаемых в документах государственных и религиозных деятелей, что снижает качество сборника и делает его малодоступным для широкого читателя. В сборнике документов, подготовленном российским исламоведом Д.Ю. Араповым, такого рода документы изложены профессионально с комментариями [3, с. 210-244].

Надо отметить и нарушение автором хронологического порядка изложения документов. Например, в шестой главе сборника доклад (представление) Председателя Закавказского шиитского духовного правления шейх-уль-ислама Ахунда-заде Главноначальствующему гражданской частью на Кавказе от 2 сентября 1902 года (с. 369-370) включён после документов 1912-1914 гг. (с. 363-368), обращение Эчмиадзинского армяно-григорианского Синода к наместнику Кавказа князю А.И. Чернышову от 27 февраля 1873 года включен между документами 1853 года (с. 494-495), в девятую главу вошли документы (с. 504-508), не имеющие никакого отношения к «религиозным притеснениям».

Нарушен автором и тематический принцип изложения документов. В частности, прошение муфтия Закавказского Духовного правления суннитов наместнику Кавказа от

19 апреля 1846 года об отводе казённой пустующей земли под строительство помещения для прилегающей мечети и училища «для воспитания детей» (c. 397) изложено не в шестой главе, а в седьмой.

Несмотря на эти и ряд других погрешностей, сборник документов Гела Гуниава «Исламская община Кавказа по документам грузинских архивов 1800-1917 гг.» для историков, исламоведов, религиоведов и даже политологов, занимающихся государственно-конфессиональными отношениями в России, представляет большую научную и источниковедческую ценность.

\section{Литература}

1. Арапов Д.Ю. Система государственного регулирования ислама в Российской империи (последняя треть XVIII - начало XX вв.). - М., 2004. - С. 3.

2. ГИААР. Ф. 290. Оп. 1. Д. 25. Л. 1-4.

3. Ислам в Российской империи (законодательные акты, описания, статистика) / сост. и автор статьи, комментариев и приложений Д.Ю. Арапов. - М.: ИКЦ «Академкнига», 2001. - С. 210-244.

\section{References}

1. Arapov D.YU. Sistema gosudarstvennogo regulirovaniya islama $v$ Rossijskoj.imperii (poslednyaya tret' XVIII - nachalo XX vv.). [The System of Public Regulation of Islam in the Russian Empire (the Last Triens of the $18^{\text {th }}-$ Early $20^{\text {th }}$ Century)]. Moscow, 2004. - S. 3.

2. GIARR, f. 290, op. 1, d. 25, 1. 1-4.

3. Islam v Rossijskoj imperii (zakonodatel'nye akty, opisaniya, statistika) / sost. i avtor stat'i, kommentariev i prilozhenij D.YU. Arapov. [Islam in the Russian Empire (Legislative Acts, Descriptions, Statistics)]. Moscow: «Akademkniga». - S. 210-244. 